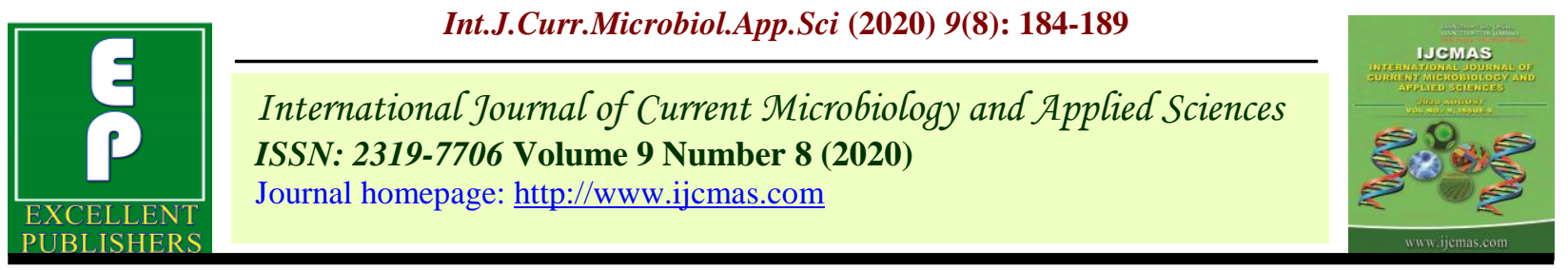

\title{
A Study of Vermicompost, Cow Dung and Phosphate Solubilizing Bacteria on Growth and Yield of Potato (Solanum tuberosum L)
}

\author{
Vikas Kumar $^{1}$, J. P. Singh ${ }^{2 *}$, Shivani ${ }^{1}$ and Himanshu Kaushik ${ }^{2}$ \\ ${ }^{1}$ School of Agriculture and Environment Sciences, Shobhit University, \\ Gangoh Saharanpur, India \\ ${ }^{2}$ Department of Horticulture, Gochar Mahavidhyalaya, Rampur Maniharan, \\ Saharanpur (U.P.), India \\ *Corresponding author
}

\begin{tabular}{|c|}
\hline Keywords \\
\hline $\begin{array}{l}\text { Vermicompost, } \\
\text { Cow dung, } \\
\text { Phosphate } \\
\text { solubilizing bacteria }\end{array}$ \\
\hline Article Info \\
\hline $\begin{array}{l}\text { Accepted: } \\
\text { 10 July } 2020 \\
\text { Available Online: } \\
10 \text { August } 2020\end{array}$ \\
\hline
\end{tabular}

A B S T R A C T

\begin{abstract}
The experiment was conducted under field condition at School of Agriculture and Environmental Sciences, Shobhit University Gangoh Saharanpur, (UP) to determine the study of vermicompost, cow dung and phosphate solubilizing bacteria on growth and yield components of Potato (Solanum tuberosum L). The Randomized Block Design (RBD) was used with four replications. A Potato cultivar Kufri Chipsona 3 was grown combined with vermicompost, cow dung and phosphate solubilizing bacteria during 2016-17 and 2017-18 both the years. There were eight treatments used in which one control and remaining seven treatments consists combination of vermicompost, cow dung and phosphate solubilizing bacteria. Growth parameters were plant height, leaf length, and stem diameter while yield parameters were tuber weight, and tuber yield were recorded. The maximum values for plant height, leaf length, stem diameter were recorded from (Vermicompost + Cow dung + PSB) respectively. However the minimum values of all the parameters were recorded from the control treatment. From the study it could be concluded that Potato yield components were greatly affected by different rates of organic and bio fertilizers. The appropriate amount of different rates of organic and biofertilizers (Vermicompost + Cow dung + PSB) should be used to increase potato yield and yield attributing character.
\end{abstract}

\section{Introduction}

Potato (Solanum tuberosum L.) belongs to the Solanaceae family, which are a major world food crop and by far the most important vegetable crop in terms of quantities produced and consumed worldwide. Potato is fourth important food crop after wheat, rice and maize in the world (Pandey et al., 2005; Reshi et al., 2013; Ezekiel et al., 2005). India is the second largest producer of potato in the world
(Saxena and Mathur, 2013). It is a rich source of carbohydrates $(22.6 \mathrm{~g} / 100 \mathrm{~g})$, starch (16.3 $\mathrm{g} / 100 \mathrm{~g})$ and proteins (1.6 g/ 100g). Potato provides a source of low cost energy to the human diet and it is the rich source of starch, vitamin $\mathrm{C}$ and $\mathrm{B}$ and minerals (Kumar et al., 2013; Lokendrajit et al., 2013).

A number of plant parameters were affected by the use vermicompost such as the plant height, foliage coverage, number of main 
stem per plant, fresh weight, dry weight of shoot, and number of tuber per pant, percent dry matter of tuber, weight of tubers per plant, tuber yield and dry weight of tuber. Nitrogen is an essential constituent of protein and chlorophyll; Phosphorus (P) is essential to increase tuber yield and nutritional quality of potato tubers (Fernandes et al., 2015).

Biofertilizers is an essential factor of organic farming play a crucial role in maintaining long term soil fruitfulness and sustainability by fixing meteorological di-nitrogen, regiment fixed macro and micro nutrients in the soil into forms available to plants (Kumar et al., 2017). The use of phosphate solubilizing bacteria as inoculants simultaneously increases $\mathrm{P}$ uptake by the plant and crop yield (Rodríguez et al., 1999).

Cow dung is very effective's manures for reducing the bacterial and fungal pathogenic disease. It showed a positive response in suppression of mycelia growth of plant pathogenic fungi like Fusarium solani, $F$. oxysporum and Sclerotinia sclerotiorum (Basak and Lee, 2002).

\section{Materials and Methods}

The experiment was conducted at the experimental site of the School of Agriculture and Environmental Sciences, Shobhit University, Gangoh Saharanpur, Uttar Pradesh (India) during the winter season (November to March) 2016-17 and 2017-18. The latitude $29^{\circ} 58 \mathrm{~N}$ and $77^{\circ} 32 \mathrm{E}$ longitude with altitude of $284 \mathrm{~m}$ above sea level, which falls under the north western plains subregion of Upper Gangatic Plains. The soil was sandy loam with $\mathrm{pH}$ 6.12. The experiment was laid out in randomized block design with four replications (Fisher, 1963). There were eight treatments, the organic and biofertilizers were also used as per treatments. In treatment $\mathrm{T}_{1}$ - Vermicompost @ 6 t/ha, $\mathrm{T}_{2}$ -
Vermicompost@6t/ha + Cow dung@10 t/ha, T 3 -Vermicompost @6 t/ha +PSB @ $10 \mathrm{~kg} / \mathrm{ha}, \mathrm{T}_{4}$ - Cow dung @ $10 \mathrm{t} / \mathrm{ha}, \mathrm{T}_{5}$ - Cow dung@10 t/ha + PSB @ $10 \mathrm{~kg} / \mathrm{ha}, \mathrm{T}_{6}$ - PSB @ $10 \mathrm{~kg} / \mathrm{ha}, \mathrm{T}_{7}$ - Vermicompost @ $6 \mathrm{t} / \mathrm{ha}+$ Cow dung@10 t/ha + PSB @ 10 kg/ha and $\mathrm{T}_{8}$ - without manure and fertilizer i.e. control were treated. The potato variety Chipsona -3 was used in this research work. Potato tubers were planted with spacing of $40 \mathrm{~cm}$ i.e. row to row distance while $30 \mathrm{~cm}$ apart from plant to plant.

\section{Results and Discussion}

The present investigation has been carried to find out the appropriate relative amount of vermicompost, cow dung and phosphate solubilizing bacteria for improving plant growth and yield parameters in response of potato (Solanum tuberosum L.). The experimental findings obtained in present studies due to application of vermicompost, cow dung and phosphate solubilizing bacteria given below in table.1, 2 and 3.

\section{Growth parameters}

The highest value (56.05 and 58.52) of plant height both the years (2016-17 and 2017-18) was recorded in treatment $\mathrm{T}_{7}$ (Vermicompost + Cow dung + PSB) and found to be statistically significant over the other treatments. The lowest plant height (29.71 and 32.31) was recorded in $\mathrm{T}_{8}$ (control). Application of treatment $\mathrm{T}_{7}$ (Vermicompost + Cow dung + PSB) gave the maximum number of compound leaves, length of leave, number of shoot and number of branches per plant both years and minimum under the treatment $\mathrm{T}_{8}$ (Control). The similar finding was also recorded by Choudhary et al., 2010; Yeptho et al., 2012. The highest fresh weight of shoot plant ${ }^{-1}$ was observed in treatment $\mathrm{T}_{7}$ and lowest fresh weight of shoot plant $^{-1}$ was recorded under treatment $\mathrm{T}_{8}$ during both years. 
Table.1 Effect of vermicompost, cow dung and phosphate solubilizing bacteria on growth attributes of potato

\begin{tabular}{|c|c|c|c|c|c|c|c|c|c|c|}
\hline \multirow[t]{2}{*}{ Treatments } & \multicolumn{2}{|c|}{ Plant height (cm) } & \multicolumn{2}{|c|}{$\begin{array}{c}\text { Number of compound } \\
\text { leave/plant }\end{array}$} & \multicolumn{2}{|c|}{ Number of shoot/plant } & \multicolumn{2}{|c|}{ Length of leave (cm) } & \multicolumn{2}{|c|}{$\begin{array}{c}\text { Number of branch } \\
\text { /plant }\end{array}$} \\
\hline & 2016 & 2017 & 2016 & 2017 & 2016 & 2017 & 2016 & 2017 & 2016 & 2017 \\
\hline $\mathbf{T}_{1}$ & 46.55 & 49.42 & 44.49 & 45.73 & 4.65 & 5.40 & 3.52 & 3.53 & 4.60 & 5.46 \\
\hline $\mathbf{T}_{2}$ & 48.27 & 50.46 & 46.00 & 47.35 & 5.25 & 5.69 & 3.74 & 3.74 & 4.94 & 5.48 \\
\hline $\mathbf{T}_{3}$ & 49.38 & 51.52 & 46.57 & 49.45 & 5.38 & 6.33 & 3.99 & 4.00 & 5.29 & 6.43 \\
\hline $\mathbf{T}_{4}$ & 44.60 & 47.51 & 42.35 & 44.10 & 4.81 & 5.36 & 3.36 & 3.37 & 4.43 & 4.55 \\
\hline $\mathbf{T}_{5}$ & 47.51 & 50.54 & 43.83 & 45.80 & 5.25 & 6.11 & 3.93 & 3.93 & 4.82 & 5.62 \\
\hline$T_{6}$ & 45.04 & 48.44 & 42.68 & 44.84 & 4.63 & 5.31 & 3.47 & 3.48 & 3.52 & 5.42 \\
\hline $\mathbf{T}_{7}$ & 56.05 & 58.52 & 54.33 & 56.03 & 6.13 & 6.56 & 4.41 & 4.42 & 6.40 & 7.37 \\
\hline $\mathbf{T}_{8}$ & 29.71 & 32.31 & 37.13 & 38.25 & 4.25 & 4.54 & 2.08 & 2.09 & 2.95 & 3.40 \\
\hline Mean & 45.89 & 48.59 & 44.67 & 46.44 & 5.04 & 5.66 & 3.56 & 3.57 & 4.62 & 5.47 \\
\hline S. Em). \pm & 0.35 & 0.15 & 0.35 & 0.36 & 0.10 & 0.14 & 0.03 & 0.03 & 0.05 & 0.13 \\
\hline C.D. at 5\% & 1.04 & 0.45 & 1.03 & 1.08 & 0.28 & 0.42 & 0.09 & 0.08 & 0.14 & 0.39 \\
\hline C.V. (\%) & 1.53 & 0.62 & 1.55 & 1.57 & 3.79 & 5.05 & 1.70 & 1.54 & 2.08 & 4.77 \\
\hline
\end{tabular}

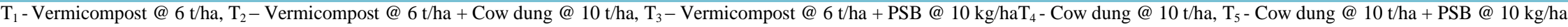

$\mathrm{T}_{6}$ - PSB @ $10 \mathrm{~kg} / \mathrm{ha}, \mathrm{T}_{7}$ - Vermicompost @ $6 \mathrm{t} / \mathrm{ha}+$ Cow dung @ $10 \mathrm{t} / \mathrm{ha}+\mathrm{PSB} @ 10 \mathrm{~kg} / \mathrm{ha}, \mathrm{T}_{8}-$ control

Table.2 Effect of vermicompost, cow dung and phosphate solubilizing bacteria on number of stolon plant ${ }^{-1}$, stolon length plant ${ }^{-1}$, fresh weight of shoot plant ${ }^{-1}$ and fresh and dry weight of tubers of potato

\begin{tabular}{|c|c|c|c|c|c|c|c|c|c|c|}
\hline \multirow[t]{2}{*}{ Treatments } & \multicolumn{2}{|c|}{ Number of stolon/plant } & \multicolumn{2}{|c|}{$\begin{array}{c}\text { Fresh weight of shoot /plant } \\
\text { (gm) }\end{array}$} & \multicolumn{2}{|c|}{ Stolon length/plant (cm) } & \multicolumn{2}{|c|}{$\begin{array}{c}\text { Fresh weight of tuber /plant } \\
\text { (gm) }\end{array}$} & \multicolumn{2}{|c|}{$\begin{array}{c}\text { Dry weight of tuber /plant } \\
(\mathrm{gm})\end{array}$} \\
\hline & 2016 & 2017 & 2016 & 2017 & 2016 & 2017 & 2016 & 2017 & 2016 & 2017 \\
\hline $\mathbf{T}_{1}$ & 13.38 & 14.29 & 84.42 & 87.00 & 5.04 & 5.40 & 199.08 & 204.21 & 32.94 & 31.28 \\
\hline $\mathbf{T}_{2}$ & 13.23 & 14.35 & 87.71 & 90.25 & 5.19 & 5.63 & 208.66 & 212.11 & 34.50 & 33.38 \\
\hline $\mathbf{T}_{3}$ & 13.64 & 14.41 & 88.76 & 91.05 & 5.29 & 5.70 & 213.40 & 218.00 & 35.26 & 33.84 \\
\hline $\mathbf{T}_{4}$ & 11.37 & 12.26 & 77.23 & 79.71 & 4.80 & 5.16 & 191.90 & 197.10 & 31.67 & 32.46 \\
\hline $\mathbf{T}_{5}$ & 13.13 & 14.41 & 85.35 & 88.35 & 5.12 & 5.57 & 202.73 & 208.08 & 33.51 & 33.42 \\
\hline $\mathbf{T}_{6}$ & 12.38 & 13.18 & 81.14 & 83.69 & 4.91 & 5.39 & 196.84 & 201.43 & 32.32 & 31.73 \\
\hline $\mathbf{T}_{7}$ & 14.24 & 15.41 & 95.70 & 97.80 & 6.12 & 6.19 & 227.22 & 232.18 & 37.57 & 36.42 \\
\hline $\mathbf{T}_{8}$ & 10.71 & 10.27 & 52.56 & 54.92 & 3.02 & 3.31 & 102.66 & 105.99 & 16.98 & 16.30 \\
\hline Mean & 12.76 & 13.57 & 81.61 & 84.09 & 4.93 & 5.29 & 192.81 & 197.39 & 31.84 & 31.10 \\
\hline S. Em). \pm & 0.15 & 0.22 & 0.60 & 0.56 & 0.01 & 0.15 & 0.49 & 0.55 & 0.08 & 0.27 \\
\hline C.D. at $5 \%$ & 0.46 & 0.65 & 1.77 & 1.65 & 0.03 & 0.46 & 1.44 & 1.63 & 0.25 & 0.81 \\
\hline C.V. (\%) & 2.42 & 3.25 & 1.47 & 1.33 & 0.40 & 5.82 & 0.50 & 0.56 & 0.52 & 1.75 \\
\hline
\end{tabular}


Table.3 Effect of vermicompost, cow dung and phosphate solubilizing bacteria on yield parameters of potato

\begin{tabular}{|c|c|c|c|c|c|c|c|c|c|c|}
\hline \multirow[t]{2}{*}{ Treatments } & \multicolumn{2}{|c|}{ Number of tubers/plant } & \multicolumn{2}{|c|}{ Number of tubers plot } & \multicolumn{2}{|c|}{$\begin{array}{c}\text { Diameter of tuber } \\
\text { /plant }\end{array}$} & \multicolumn{2}{|c|}{ Total yield (kg plot ${ }^{-1}$ ) } & \multicolumn{2}{|c|}{ Total yield $\left(q\right.$ ha $\left.^{-1}\right)$} \\
\hline & 2016 & 2017 & 2016 & 2017 & 2016 & 2017 & 2016 & 2017 & 2016 & 2017 \\
\hline $\mathbf{T}_{1}$ & 7.06 & 7.63 & 740.78 & 745.34 & 4.14 & 4.57 & 14.96 & 15.07 & 118.73 & 119.78 \\
\hline $\mathbf{T}_{2}$ & 7.45 & 8.22 & 781.73 & 765.09 & 4.28 & 4.80 & 17.05 & 17.11 & 135.40 & 135.75 \\
\hline $\mathbf{T}_{\mathbf{3}}$ & 8.10 & 8.23 & 850.76 & 819.33 & 4.46 & 4.76 & 16.31 & 17.13 & 129.40 & 135.93 \\
\hline $\mathbf{T}_{4}$ & 5.93 & 7.31 & 622.13 & 663.56 & 4.11 & 4.59 & 13.18 & 13.19 & 104.56 & 104.66 \\
\hline $\mathbf{T}_{5}$ & 7.41 & 8.17 & 778.05 & 761.30 & 4.34 & 4.74 & 15.05 & 15.90 & 119.46 & 126.19 \\
\hline $\mathbf{T}_{6}$ & 6.50 & 7.42 & 682.76 & 696.42 & 4.20 & 4.52 & 13.41 & 14.21 & 106.43 & 112.77 \\
\hline $\mathbf{T}_{7}$ & 8.80 & 9.58 & 923.48 & 952.63 & 4.78 & 4.84 & 23.84 & 25.17 & 189.16 & 199.78 \\
\hline $\mathbf{T}_{8}$ & 3.85 & 4.49 & 403.99 & 446.90 & 3.08 & 3.23 & 7.61 & 7.62 & 60.35 & 60.49 \\
\hline Mean & 6.89 & 7.63 & 722.96 & 731.32 & 4.17 & 4.50 & 15.17 & 15.67 & 120.44 & 124.42 \\
\hline S.Em). \pm & 0.18 & 0.18 & 18.99 & 0.73 & 0.04 & 0.06 & 0.27 & 0.25 & 2.13 & 1.96 \\
\hline C.D. at $5 \%$ & 0.54 & 0.52 & 56.22 & 2.17 & 0.12 & 0.17 & 0.79 & 0.73 & 6.32 & 5.81 \\
\hline C.V. $(\%)$ & 5.25 & 4.62 & 5.25 & 0.20 & 1.94 & 2.57 & 3.53 & 3.16 & 3.54 & 3.16 \\
\hline
\end{tabular}

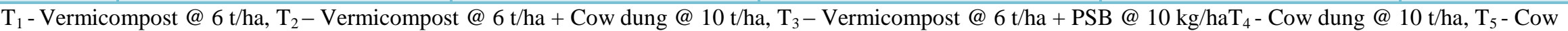
dung@10t/ha+PSB@10 kg/ha, T - PSB @ $10 \mathrm{~kg} / \mathrm{ha}, \mathrm{T}_{7}$ - Vermicompost @ $6 \mathrm{t} / \mathrm{ha}+$ Cow dung @ $10 \mathrm{t} / \mathrm{ha}+\mathrm{PSB} @ 10 \mathrm{~kg} / \mathrm{ha}, \mathrm{T}_{8}-\mathrm{control}$ 


\section{Yield parameters}

During the first year (2016-17) of investigation the maximum number of stolon plant $^{-1}$ (14.24) was observed under the treatment $\mathrm{T}_{7}$ (Vermicompost + Cow dung + PSB). The minimum number of stolon plant ${ }^{1}$ (10.71) was counted under the treatment $T_{8}$ (control). A recitation of the data clearly indicates that significantly maximum number of stolon plant ${ }^{-1}$ (15.41) during 2017-18 was counted under the treatment (Vermicompost + Cow dung + PSB). The minimum number of stolon plant ${ }^{-1}$ was counted in the treatment control (10.27). The maximum length of stolon was also found in $T_{7}$ treatment and minimum length of stolon was found $T_{8}$ treatment both the years.

The maximum fresh and dry weight of potato was observed in the treatment (Vermicompost + Cow dung +PSB). While the minimum fresh and dry weight of potato noticed under the treatment (Control) both years. The similar finding was also recorded by (Alam $e t$ al., 2007); (Nag 2006). Maximum number of tuber $\operatorname{plant}^{-1}$ (8.80 and 9.58) was obtained with the application of treatment $\mathrm{T}_{7}$ (Vermicompost + Cow dung +PSB) and while the minimum number of tuber plant ${ }^{-1}(3.85$ and 4.49) was observed under treatment $\mathrm{T}_{8}$ (Control) during both years 2016-17 and 2017-18. The similar finding was also recorded by (Jaipaul et al., 2011).

Maximum number of tuber $\operatorname{plot}^{-1}$ was obtained with the application of treatment (Vermicompost + Cow dung +PSB) and while the minimum number of tuber plot $^{-1}$ was observed under treatment (Control) during both years. The highest value of the diameter of tuber plant ${ }^{-1}$ was noticed $T_{7}$ and lowest value diameter of tuber plant ${ }^{-1}$ was observed under the treatment $\mathrm{T}_{8}$ during both years. The maximum total tuber yield $(\mathrm{kg})$ plot $^{-1}(23.84$ and 25.17) was recorded under the treatment
(Vermicompost + Cow dung +PSB). The minimum total tuber yield $(\mathrm{kg}) \mathrm{plot}^{-1}(7.61$ and 7.62) was noticed the treatment (Control) both years.

During the first year (2016-17) of investigation the highest total tuber yield $\mathrm{q} / \mathrm{ha}$ (189.16) and second year (2017-18) the highest total tuber yield q/ha (199.78) was recorded under the treatment $\mathrm{T}_{7}$ (Vermicompost + Cow dung +PSB). While the lowest total tuber yield q/ha (60.35 and 60.49) was observed under the treatment $T_{8}$ (Control) both years. The similar finding was also recorded by (Kumar et al., 2015).

In conclusion based on two year data present study manifest that vermicompost combined with cow dung and bio fertilizers increased the potato growth and yield. Based on the findings of the experiment, treatment $\mathrm{T} 7$ (Vermicompost + Cow dung +PSB) were more profitable than the rest of the treatment combinations. So vermicompost is a best source for potato production. It can be concluded that combined of potato tuber with vermicompost, cow dung and PSB showed significantly higher plant height, number of compound leave, number of branch, number of shoot, length of leave, number of stolon, number of tuber, tuber weight and tuber yield, as compare to other treatments is shown both years 2016-17 and 2017-18.

\section{References}

Alam, M. N., Jahan, M.S., Ali, M.K., Ashraf, M.A. and Islam, M.K. (2007). Effect of vermicompost and chemical fertilizers on growth, yield and yield components of potato in barind soils of Bangladesh. J. Appl. Sci. Res., 3(12): 1879-1888.

Basak, A.B. and Lee, M.W. (2002) In vitro inhibitory activity of cow urine and cow dung of Fusarium solani f. sp. Cucurbitae. Microbiology 30: 51-54.

Choudhary, Anil K, Rahi Shakuntla, Singh Amar 
and Yadav DS. (2010). Effect of vermicompost and biofertilizers on productivity and profitability in potato in north-western Himalayas. Current Advances in Agricultural Sciences 2(1): 18-21

Ezekiel, R., Mehta, A., Singh B., Kumar, D., Ranjan Kumar, N., Paul, V. and Das, M. (2005). CIPC for sprout suppression in potatoes during storage. Technical Bulletin No. 69, Central Potato Research Institute, Shimla, India. p. 50.

Fisher, R.A. and F. Yates (1963). Statistical tables for biological agricultural and medical research. 6Aufl. Oliver \& Boyd, London 146 S. Preis 30.

Fernandes, Adalton Mazetti, Soratto Rogério Peres, Moreno Leticia de Aguila, Evangelista Regina Marta (2015). Effect of phosphorus nutrition on quality of fresh tuber of potato cultivars. Bragantia 74 (1): 1678-4499.

Jaipaul, Sharma, S. and Sharma, A.K. (2011). Effect of organic fertilizers on growth, yield and quality of potato under rainfed conditions of central Himalayan region of Uttarakhand. Potato J. 38 (2): 176-181.

Kumar, Rakesh, Kumawat Narendra and Kumar Sahu Yogesh (2017). Role of biofertilizers in agriculture. Pop. kheti, 5(4): 63-66 www.popularkheti.info.

Kumar, Rajesh, Singh, Avtar, Hooda Vikash, Singh, R. K and Singh Mainpal (2015). Effect of organic manures, bio-fertilizer and mulching on growth and yield of potato (solanum tuberosum 1.) An international quarterly journal of life science 10 (1): 403-406.

Kumar, Manoj, Baishya, L. K., Ghosh, D.
C., Ghosh, M., Gupta, V. K., Verma, M. R. (2013). Effects of organic manures, chemical fertilizers and biofertilizers on growth and productivity of rainfed potato in the eastern Himalayas. Journal of Plant Nutrition 36 (7): 1065-1082 ref.23.

Lokendrajit, N, Singh CB, Swapana N and MS Singh (2013). Evaluation of nutritional value of two local potato cultivars (Aberchaibi and Amubi) of Manipur, Northeast India. Bioscan 8: 589-593.

Nag, G.P. (2006). Integrated nutrient management in potato for Chhattisgarh plains. M.Sc. (Ag) Thesis IGKV, Raipur. pp. 94-95.

Pandey, SK, Singh, SV and D Sarkar (2005). Potato (Solanum tuberosum) for sustaining food and nutrition security in developing world. Indian Journal Agric Science 75: 318.

Reshi, M, Bhat A, Kaul, RK and M Gupta (2013). Evaluation of various potato cultivars of Jammu region for processing attributes. Bioscan 8: 1203-1205.

Rodríguez, Hilda and Fraga Reynaldo (1999). Phosphate solubilizing bacteria and their role in plant growth promotion. Biotechnology Advances 17 (4-5): 319339.

Saxena, R. and Mathur, P. (2013). Analysis of potato production performance and yield variability in India. Potato J. 40 (1): 38-44.

Yeptho, V, Kanaujia, SP, Singh, VB and Sharma A. (2012). Effect of integrated nutrient management on growth, yield and quality of tomato under poly house condition. J. Soils and Crops, Nagpur 22 (2): 246-252.

\section{How to cite this article:}

Vikas Kumar, J. P. Singh, Shivani and Himanshu Kaushik. 2020. A Study of Vermicompost, Cow Dung and Phosphate Solubilizing Bacteria on Growth and Yield of Potato (Solanum tuberosum L). Int.J.Curr.Microbiol.App.Sci. 9(08): 184-189.

doi: https://doi.org/10.20546/ijcmas.2020.908.020 